\title{
FORMULATIVE POLICY OF DEATH PENALTY FOR \\ CORRUPTORS IN INDONESIA
}

\section{Ni Wayan SINARYATI (iD) $1 *$}

I Gede ARTHA (iD) 2

1 Udayana University Denpasar, Faculty of Law, Doctoral Study Program, wayansinaryati.fh@gmail.com, , * Correspondent Author

2 Udayana University Denpasar, Faculty of Law, Doctoral Study Program,igedeartha58@gmail.com

\begin{tabular}{|c|c|}
\hline Article history: & A b s t r a c t \\
\hline $\begin{array}{l}\text { Accepted } 10 \text { June } 2020 \\
\text { Available online } 31 \text { August } 2020\end{array}$ & Corruption is committed by state officials, law enforcement and other related parties. Various efforts \\
\hline & have been made by the government in preventing and eradicating corruption in Indonesia, but the \\
\hline Keywords: & efforts that have been made have not yet gotten optimal results. The fundamental weakness in \\
\hline Policy Formulation, & eradicating corruption in Indonesia is the formulation of the main criminal sanctions in the form of \\
\hline Death Penalty Sanctions, & criminal threats that are facultative, uncertain or must be. So that the corruptors are never deterred \\
\hline Corruptors. & or afraid. In the future, the legislators need to reformulate the provisions of Article 2 paragraph (2) \\
\hline & $\begin{array}{l}\text { of the Republic of Indonesia Law Number } 31 \text { of } 1999 \text { as amended to Law of the Republic of } \\
\text { Indonesia Number } 20 \text { of } 2001 \text { concerning Eradication of Corruption. Various criminal law policies }\end{array}$ \\
\hline
\end{tabular}

This type of research in this paper uses the type of normative legal research. The type of approach is in the form of a legal approach related to corruption. There are two legal materials used, namely primary legal materials and secondary legal materials, with legal material collection techniques used in the form of library studies. The analysis technique used is descriptive, interpretation, evaluation and argumentative techniques. The research in this paper intends and aims to examine and analyze the facts and phenomena of corruption that are stated in specific legislation concerning criminal sanctions (capital punishment) for corruptors in Indonesia. Moreover, corruption is qualified as an extraordinary crime so it needs extraordinary handling as well.

\section{Introduction}

Behaviors, attitudes, statements are not always held fast as commitment to oneself. Psychological disorders of a law will be tested when faced with the lure of a pile of banknotes with fantastic nominal value. The phenomenon of the above situation and position as well as the facts have proven in the statement of a former Chief Justice of the Constitutional Court, Judge M. Akil Mochtar who is currently serving a life sentence for corruption, as quoted by Muhammad Yusuf (2013), his statement when it highlighted the existence of corruption in Indonesia, with: "Corruption in Indonesia has reached its pulse. Corruption in this country is so severe, deep-rooted, even entrenched. Corruption practices occur in almost every layer of the bureaucracy, both legislative, executive and judicial, and have also spread to the business world. Like a disease, corruption is a chronic disease, so it is very difficult to treat it".

Conscious or not, remember or not M. Akil Mochtar once made a statement of his attitude towards the corruption pandemic that occurred in Indonesia like that of the former Chief Justice of the Constitutional Court and former Advocate, now for him to be a material for self-reflection and introspection, to be aware of his actions that have denied the principle his life, violated the oath of office when he was appointed as a high state official in various top positions in a country based on the Pancasila state law and ideology. Rice has become porridge, regret always comes later. 
Hopefully now for him arises a sense of regret accompanied by an attitude of repentance as an effort to redeem the great sins he has done for the nation and nation of Indonesia.

The act of the corruptor who caused the greatest sin for him was to betray the goals of the proclamation of the country on August 17,1945 which had a significant impact on the actions of harming the country's finances and disrupting the economy. Corruption phenomenon in Indonesia as described above is related to the fact according to the findings of Transparency International Indonesia (TII) released its data that the Corruption Perception Index (CPI), that the existence of Indonesia's position in 2019/2020 shows the score of the Indonesian Perception Index currently at position number 40 with the highest score of 100, CPI assessment is based on a score of 0 (zero) with very corrupt qualifications, and with a score of 100 (one hundred) means a country is free from corruption. When viewed according to the ranking of the position of the countries in the world, Indonesia is in the ranking of 85 (eighty-five) of the 180 (one hundred eighty) countries surveyed.

The Percepcy Corruption Index refers to the existence of 13 (thirteen) surveys and from expert assessments to measure public sector corruption in 180 countries and territories in the world. According to his findings, that Indonesia's position at the level of corruption is the same as 5 (five) countries such as Burkina Faso, Guyana, Leshoto, Kuwait, and Trinidad and Tobago, then overtake Indonesia. When explored further, that the most corrupt countries according to TII's findings are the Countries of Somalia, South Sudan, Syria, Yemen and Venezuela. The opposite situation, countries clean of corruption according to the results of an initial survey in 2020 with a score of 87 is in the countries of Denmark and New Zealand, followed by Finland with a score of 86 , and there are 3 (three) countries having the same score of 85 , these countries are Singapore, Sweden and Switzerland.

Related to the amount of state financial losses that cannot be recovered into Indonesian state treasury, according to a search from ICW (Indonesian Corruption Watch), in the range of 2018 it reached a quite fantastic amount with a nominal value of 9.29 Trillion Rupiah. And according to ICW data, there are 271 cases recorded of corruption that occurred throughout 2019, with state financial losses reaching 8.4 Trillion Rupiah, with 580 corruptors. As one example of corruption in Indonesia that occurred in 2019 involving a public official/ state organizer (in this case the East Waringin City Regent with the initials $\mathrm{SH}$ ) with the mode of issuance of mining business licenses which turned out to be fabricated and fictitious resulting in state financial losses ranging $5.8 \quad$ Trillion Rupiah (https://nasional.kompas,com/read/2020/01/23/16565951/indeks -persepsi-korupsi-indonesia-pada-2019 naik-jadi-40).
Based on the phenomena and facts above, it shows that the criminal acts of corruption that occurred in Indonesia where the perpetrators involved public officials and state administrators prove that the corruption that occurred as a cause of the decline in national development activities. The amount of state financial losses that have not been returned to the state treasury which is unknown is the main cause of obstruction of the mandate of the Opening of the 1945 Constitution of the Republic of Indonesia. The Indonesian people who are just and prosperous and prosperous still remain mere dreams and delusions.

Based on the background explanation above, the problems of this writing are: (1). Why are there no corruption perpetrators sentenced to death in Indonesia? (2). How is the formulation policy for capital punishment for perpetrators of corruption in the perspective of ius constituendum? This writing is an original scientific paper or it is not the same as other previous scientific papers. The scientific papers related to this topic with other previous scientific papers include: (1). "The Criminal Law Formulation Policy in Corruption Crime Mitigation", written by Ridwan, from Diponegoro University, Semarang, with the formulation of the problem: a. What is the policy on the formulation of corruption in the current legislation? $\mathrm{b}$. What is the policy formulation for the upcoming corruption? (2). "The Existence of the Corruption Eradication Commission in Corruption Judiciary in Indonesia", written by Abdul Kholik, M. (2011), from the Islamic University of Indonesia, in 2011, with the formulation of the problem: a. Does the Corruption Eradication Commission need to coordinate with the Attorney General's Office? B. What is the form of cooperation between the KPK and the prosecutor's office in eradicating corruption in Indonesia? (3). "Analysis of the Corruption Criminal Prosecution Authority by the Corruption Eradication Commission (KPK) and the Prosecutor's Office according to Indonesian Positive Law", written by Syabilal Jihad, in 2018, with the formulation of the problem: a. Is there no dualism in prosecuting corruption in Indonesia? b. What are the criteria in the prosecution of corruption cases carried out by the Corruption Eradication Commission (KPK)?

Based on the presentation in the form of the title and formulation of the problems that existed in the previous scientific writings above, compared to the writings of the author, both the title and the problem are different. The author presents the title regarding capital punishment for corruptors, with the problem of why corruptors in Indonesia are not sentenced to death by law and in the future policies need to have a formulative policy regarding capital punishment for corruptors. 


\section{Research Method}

This research uses normative legal research, according to I Made Pasek Diantha (2017), stated that normative legal research is a method that examines positive legal rules of internal perspective, the object of research is legal norms. The approach used in this scientific work is in the form of a legal approach and a case approach. Sources of legal materials used are primary legal materials related to applicable laws relating to corruption such as the Corruption Eradication Act, the UN Convention concerning Corruption Crimes (UNCAC and UNCATOC). Secondary legal materials include the results of previous research, legal textbooks, scientific journals, newspapers, and tertiary legal materials such as dictionaries, encyclopedias, and internet sites that are relevant to the problem under study.

\section{Results and Discussion}

\subsection{Essence of Corruption and Death Penalty}

\subsubsection{Terminology, Definition, Characteristics and Impact of Corruption}

The term corruption is etymologically derived from Latin, namely "corruptio" or "corruptus" which then appears in many European languages such as English and French, namely "corruption", in Dutch "korruptie" which subsequently also appears in the Indonesian treasury: corruption, which can mean like being bribed (Hamzah, 1995). Corruption also comes from the word "corrupteia" or "bribery" which means to give or give it to someone so that the person has done for the benefit of the giver, or also means seducation which means something that is interesting for someone to deviate (Koeswadji, 1994). The interesting thing is usually associated with power, which is generally in the form of bribery, embezzlement and the like.

The term corruption in the Indonesian General Dictionary as concluded by Poerwadarminta is a bad act such as embezzlement, receipt of bribes and so on. Regarding the term corruption itself, according to Sudarto (2007), it began to be general in nature and only became a legal term for the first time in the Military Ruling Regulation Number PRT/PM/06/1957, concerning Eradicating Corruption.

In the legal sense as affirmed in Act Number 31 of 1999 concerning Eradication of Corruption, as amended by Act Number 20 of 2001 concerning Amendment to Law Number 31 of 1999 concerning Eradication of Corruption. Corruption is a disease that often occurs especially in developing countries like Indonesia, where the development of Indonesia's corruption is considered by some experts to be very alarming. M. Abdul Kholik (2011) stated: "For the Indonesian people, it seems to have been destined as a problem that seems to never run out to be discussed".
Even the Working Team of the National Commission on Human Rights noted, there are fundamental issues for hampering the fulfillment of the protection and respect for human rights and placing corruption as the main factor hampering such protection (Amidhan, 2006). Thus the acute corruption in Indonesia, Azhar (2009) stated: "That corruption is a social disease that is universal and has occurred since the beginning of the human journey".

Such a broad impact on corruption will basically be a very serious threat to the survival of the nation and state. Even Romli Atmasasmita (2005) stated: "That the problem of corruption has become a serious threat to the stability and security of the national and international community". On the basis of such conditions there is a lameness in the portion of income received by various groups of people referred to as relative inequality or there is an absolute level of poverty. (absolute poverty). Such conditions are certainly the most disadvantaged are the people at the grassroots level, which should receive welfare guarantees in accordance with the guarantees set forth in the constitution.

This is confirmed in Article 33 paragraph (3) of the 1945 Constitution of the Republic of Indonesia: "The earth, water, and natural resources contained therein are controlled by the state and used for the greatest prosperity of the people. Constitutionally the people's welfare is a human right that must be realized by the government as the organizer of the state, one of the efforts is the utilization of existing natural resources, which in its use is for the greatest prosperity of the people (Ridwan, 2009). As a rich country with all abundant natural resources, it is inappropriate for the Indonesian people to live in poverty and misery with a variety of sadness, from malnutrition to the problem of inability to fulfill decent living needs and adequate health.

Corruption with such a broad impact that according to the UN Convention in the UNCAC-2003 protocol (United Nations Convention Against Corruption-2003) which is a translation of the United Nations Convention on UNCATOC (United Nations Convention Against Transnational Organized Crime-2000), that corruption crime is interpreted as a crime serious because according to Tom Obokata (2015): "That corruption according to the convention is intended to get directly or indirectly financial or other material benefits".

The qualifications of corruption crimes besides being classified as extraordinary crimes have also penetrated jurisdictions across national borders. Transnational crime is given meaning or understanding by Passas N. (2003) as follows: "Cross-border crime is behavior that endangers the interests protected by law in more than one national jurisdiction and is criminalized in at least one of the countries or jurisdictions related ". 
Corruptors often run and hide outside the jurisdiction of their home country to make it difficult to find them to be arrested and processed legally. So the corrupt home government requires cooperation between countries and between law enforcers through bilateral and multilateral legal means among countries parties to the 2003 UNCAC convention. In fact, according to Harkristuti Harkrisnowo (2002): opportunity or means available to him". According to Marella Buckley (2003): "Corruption is the misuse of public office for personal gain through bribery or illegal commissions". In line with the opinion above, Indriyanto Seno Adji (2006) stated: "It is undeniable that corruption is a White Collar Crime with actions that always undergo dynamic mode of operation from all sides so that it is said to be Invisible Crime whose handling requires criminal law policies".

This criminal law policy must certainly have the characteristics of the values of justice that can be felt by all Indonesian people, so the main consideration is in favor of the people's economic interests or the public interest. Regarding actions that include corruption, Carl J. Friedrich, as quoted by Martiman Prodjohamidjojo (2009), argues that:

"The pattern of corruption can be said if a person holds the authority that is authorized to do certain things such as an official who is responsible through money or some other kind of gift that is not permitted by law; persuading to take steps that help anyone who provides gifts and thus truly endanger the public interest." Responding to this corruption problem, Robert Klitgaard (2008) critically states that "Corruption exists when someone illegally places personal interests above the interests of the community and something entrusted to him to do so. Corruption takes many forms and can range from small to monumental. Corruption can involve misuse of policies, tariff provisions, and credit, irrigation and housing system policies, law enforcement and regulations relating to public safety, contract implementation and loan repayment or involve simple procedures. That can happen to the private sector or the public sector and often occurs in both sectors simultaneously. It can be widespread, in a number of developing countries, corruption has become systemic. Corruption can involve promises, threats or both; can be started by a civil servant or community concerned, can involve illegal or legitimate work; can be inside or outside public organizations. The boundaries of corruption are very difficult to define and depend on local laws and customs".

According to the author, the formulation given by Robert Klitgaard above shows that corruption is a crime that is of extraordinary quality and quantity and can significantly undermine the interests of the people's economy. Ronny Rahman
Nitibaskara (2005) even stated: "Corruption in our society has become endemic which is difficult to overcome. Corruption is not an extraordinary crime, only the quality and quantity of breeding is extraordinary".

\subsubsection{Existence of Death Penalty and its Relationship with Corruption}

In the legal literature, not enough is found in the notion of capital punishment by scholars or legal experts. Most notions of capital punishment are found in language dictionaries, which also use the term "capital punishment". Yon Artiono Arba'i (2012), uses the term death sentence and interprets it by quoting the meaning of the Big Indonesian Dictionary. According to him, the death sentence was defined as "a sentence carried out by killing a guilty person". In addition to using the term death sentence, in the Big Indonesian Dictionary also found the term death sentence which is interpreted as: "Criminal form of revocation of the life of the convict". A death sentence can also be interpreted as a criminal or reaction to or misery in the form of death imposed on a person who commits a criminal offense, whereas the meaning of death taken from the word basic death means the loss of a person's life or no longer alive. This death will occur through the failure of the function of one of the three pillars of life (Modi of Death), namely: brain (central nervous system), heart (circulaty of system), and lungs (respiratory of system)" (Amri, 2007).

Capital punishment is the heaviest of all types of basic crimes, so that it is only threatened against certain perpetrators. So far the need for capital punishment to be threatened against perpetrators raises many opinions. Capital punishment is exceptional in nature, meaning that capital punishment is only handed down by judges if absolutely necessary. Capital punishment is always threatened alternatively with other basic crimes, this is the choice of the judge so that the death penalty is not carried out arbitrarily. If a person is found guilty by a judge found guilty of a serious crime as a crime threatened with capital punishment, the judge can impose capital punishment. In practice, the execution of capital punishment can be postponed until the President gives Fiat Execution, meaning that the President approves the implementation of capital punishment to the convicted person (Lumintang, 2010).

In law enforcement for crimes that are extraordinary and serious in nature, capital punishment sanctions are still relevant to be carried out, according to Hendarman Supandji (2008) Indonesia still requires capital punishment as a threat to prevent and frighten potential criminal offenders. The same thing is also illustrated that capital punishment sanctions need to be maintained in order to prevent and eradicate serious and other serious crimes such as 
narcotics abuse and other extraordinary crimes (Winandi \& Lukito, 2010).

Based on the history of capital punishment is not a criminal form that is relatively new in the course of the Indonesian nation. This death sentence has been known since the days of the kingdoms. In positive Indonesian law we recognize the existence of capital punishment or capital punishment. In the Criminal Code Chapter II regarding Criminal Law, Article 10 states about various types of criminal acts, which consist of basic and additional crimes, and capital punishment including the main criminal types which rank first. Other laws and regulations in Indonesia also include threats of punishment in the form of capital punishment, for example RI Law 7/Drt/1955 concerning Economic Crimes, RI Law 35/2009 concerning Narcotics and Psychotropic Crimes, Republic of Indonesia Law Number 31 of 1999 as amended by Republic of Indonesia Law Number 20 of 2001 concerning Eradication of Corruption, Indonesian Law Number 26 of 2001 concerning Crimes Against Human Rights and Indonesian Law Number 5 of 2010 about Terrorism

Roeslan Saleh (1978) said that the Indonesian Penal Code limits the possibility of capital punishment for a number of serious crimes. What is meant by serious crimes are:

1. "Article 104 (plots against the president and/or vicepresident);

2. Article 111 paragraph 2 (inducing a foreign country to be hostile or to fight, if hostility is carried out or become a war);

3. Article 124 paragraph 3 (assisting enemies during war);

4. Article 140 paragraph 3 (treason against the king or head of friendly countries planned and resulting in death);

5. Article 340 (premeditated murder);

6. Article 265 paragraph 4 (theft by force resulting in serious injury or death);

7. Article 368 paragraph 2 (extortion with violence resulting in serious injury or death);

8. Article 444 (piracy at sea, coast and river resulting in death)".

Debate arose when many people began to ask whether capital punishment was still relevant or appropriate as a punishment in Indonesia. The question was asked not without reason, but most of them consider capital punishment violates Human Rights (HAM), namely the right to life. That right is contained in the 1945 Constitution of the Republic of Indonesia NAD Article 28A which states: "Every person has the right to live and has the right to defend his life and life". Based on this understanding they assume that the right to life is the most fundamental right and cannot be reduced under any circumstances (non derogable rights) (Lubis \& Lay, 2009).

Both the pros and cons, the reasons given all rely on Human Rights (HAM). It is necessary to elaborate on the arguments for both, of course by still referring to national law (Waluyadi, 2009). The tendency of experts who agree with capital punishment is still maintained, generally based on conventional reasons, namely capital punishment is needed to eliminate people who are considered endangering public or state interests and are deemed irreparable, while those who are contravened of capital punishment usually make excuses capital punishment is contrary to human rights and is a form of crime that cannot be remedied if after the execution is carried out an error is found in the sentence handed down by the judge.

Regarding Human Rights (HAM), in Indonesia also protects it with laws and regulations. This is indicated by the existence of a law regulating human rights, namely RI Law Number 39 of 1999 concerning Human Rights (hereinafter referred to as the Human Rights Law). In this Human Rights Law, the right to life is listed in Article 9 paragraph (1) which states:

"Everyone has the right to life, maintain life, and improve their standard of living. The right to life is even inherent in newborn babies or people sentenced to death. In cases or circumstances that are extraordinary, namely in the interest of his mother's life in an abortion case or based on a court decision in a capital punishment case, then the act of abortion or capital punishment in that case or condition, may still be permitted. Only in these two cases can the right to life be restricted".

At a glance the article above does not mean the meaning of the provisions of Article 28A of the 1945 Constitution of the Republic of Indonesia which states: "Every person has the right to live and has the right to defend his life and life". Based on the explanation of Article 9 paragraph (1) of the Human Rights Law, it can be underlined in the sentence ".... based on the court's decision in the case of capital punishment, the act of abortion or capital punishment in this case or condition, can still be permitted ..." so that it can the conclusion is drawn, that in these circumstances the right to life can be removed.

That in the context of Indonesia was confirmed in the Constitutional Court Decision Number 2-3/PUU-V/2007 concerning Judicial Review of Law Number 22 of 1997 concerning Narcotics which states that in the future the formulation, implementation, and implementation of capital 
punishment should pay attention to the four important things, namely:

1. "First, capital punishment is no longer a basic crime, but as a special and alternative crime;

2. Second, the death penalty can be sentenced to a tenyear probation which if the convicted convict behaves can be amended with a life sentence of 20 years;

3. Third, capital punishment cannot be imposed on minors;

4. Fourth, the execution of capital punishment against pregnant women and mentally ill people is suspended until the pregnant woman gives birth and the mentally ill convict is declared healed".

At present in the Criminal Code Bill, capital punishment is a specific primary crime and is always threatened by alternatives. Although not included as a principal crime, capital punishment is still recognized as a special form of primary crime.

\subsubsection{Policy on the Formulation of Death Penalty Threats in the Corruption Eradication Act}

According to Robert R. Mayers and Ernest Greenwood, as quoted by Sultan Zanti Arbi and Wayan Ardana (1997), the term "policy" is taken from the terms "policy" (English) or "politiek" (Dutch). Related to the substance of criminal law policies, according to Barda Nawawi Arief (2002):

Basically, the problem of criminal law policy is not merely legal engineering work that can be done in a normative and systematic dogmatic manner. Besides factual juridical approaches can also be in the form of a sociological, historical and comparative approach, even requiring an integral approach to social policy and national development in general.

Barda Nawawi Arief (2002) further stated, the pattern of the relationship between penal policy and crime prevention efforts must be used with an integral approach and there is a balance between "penal" and "non-penal". Prevention and crime approach by means of "penal" is a "penal policy" or "penal law enforcement policy" whose function is through several stages, namely:

a. "Formulation (legislative/legislative policies);

b. Application (judicial/judicial policy), which is the stage of applying criminal law by law enforcement officials from the police to the court, which can also be referred to as the stage of judicial policy;

c. Execution (executive/administrative policy), which is the stage of implementing criminal law which can also be called the executive or administrative policy stage" (Mulyadi, 2012).

Efforts and policies to make good criminal law regulations in essence cannot be separated from the purpose of overcoming crime by using criminal penalties. Crime prevention efforts with criminal law are essentially also part of law enforcement efforts (specifically criminal law enforcement). Because of this, it is often said that criminal law policies are part of the law enforcement policy.

The policy of regulating death penalty formulations in the Corruption Eradication Act is currently only 1 (one) article that regulates it, namely in Article 2 paragraph (2) and supplemented with the Elucidation of Article by Article in Article 2 paragraph (2). The full article cited again in Article 2 paragraph (2) and its explanation in the Corruption Eradication Law, namely:

- $\quad$ Article 2 paragraph (2): "In the event that a criminal act of corruption as referred to in paragraph (1) is carried out under certain circumstances, the death penalty may be imposed".

- $\quad$ Elucidation of Article 2 paragraph (2): "What is meant by certain circumstances in this provision is a condition that can be used as a reason for criminal prosecution for corruptors, that is if the crime is committed against funds intended for the handling of a state of danger, natural disaster national level, countermeasures due to widespread social unrest, overcoming the economic and monetary crisis, and repetition of criminal acts of corruption ".

It must be admitted, with the inclusion of the formulation of capital punishment in the Corruption Eradication Act on the one hand shows the seriousness and serious intentions of the government and also the Parliament to eradicate or at least reduce the crime of corruption, which is in the statutory regulations the existing regulations on capital punishment were never stated. Nevertheless, it must also be stated honestly, the formulation policy or formulation of the death penalty listed in the Corruption Eradication Act thus gives the impression of "seriousness" of the legislators to implement the death penalty and contains several weaknesses.

Some weaknesses in the Corruption Eradication Act related to the formulation of capital punishment (Article 2), according to the author, can be summarized in 2 (two) types of weaknesses, namely:

1. Formal Weakness;

2. Material Weakness (substance). 
Formal weaknesses, i.e. weaknesses related to the problem of compilation and/or editorial choice of sentences, namely in the case of: The use of the phrase "certain circumstances" and "can" be dropped. That the formulation of "certain circumstances" which is the reason for the imposition of a criminal offense for the death penalty can not be formulated clearly and clearly in the formulation of the article. In various formulations of the law both inside the Criminal Code and outside the Criminal Code, "certain circumstances" which are the reasons for criminal charges are generally formulated explicitly and clearly in the formulation of the relevant offense. In the Criminal Code for example, criminal charges for abuse in Article 356 of the Criminal Code and criminal charges for theft in Article 365 of the Criminal Code, all of them are stated explicitly and clearly in the formulation of these articles. Likewise, the formulation of articles which includes capital punishment in the Narcotics Act or the Terrorism Act.

The formulation of "certain circumstances" contained in Article 2 paragraph (2) of the Corruption Eradication Act which is the reason for the imposition of capital punishment was not formulated explicitly and clearly in the formulation of the article, but was included in the Elucidation of Article 2 paragraph (2) of the Eradication Act Corruption Crime. This condition creates a blurring of norms because an explanation both general explanation and article by article explanation in a statutory regulation cannot be used as a basis for making new regulations and may not contain or create new norms. This is in accordance with Appendix I of RI Law Number 12 of 2011 concerning Formation of Laws and Regulations number 177, which is explained explicitly: "Explanation cannot be used as a legal basis for making further regulations and may not include formulations that contain norms".

The formulation of the phrase "can" be dropped stated in the formulation of Article 2 paragraph (2) of the Corruption Eradication Act also has clearly caused bias in its implementation because it depends on the subjectivity of law enforcement, in this case the judge who hears and decides cases of corruption the. The formulation of the phrase "can" in its implementation will be interpreted "can be applied" or "can also not be applied". In this context the judge can use his authority to interpret the phrase "can" as "can be sentenced to death" or vice versa "can not be sentenced to death".

As an illustration in RI Law Number 30 Year 2014 concerning Government Administration, Article 23 letter a and its Explanation are stated: "One of the discretion of a government official is characterized by the word" can "which means a choice to implement or not implement a decision and/or action. Sounds Article 23 letter a and the explanation as follows:

- $\quad$ Article 23 letter a:

Government Officials' discretions include:

1. "Decision making and/or action based on statutory provisions that provide a choice of decisions and/or actions";

- Explanation of Article 23 letter a: "Choice of Decisions and/or Actions of Government Officials is characterized by the word can, may, or be given authority, rights, should, be expected, and other similar words in the provisions of the legislation. Whereas what is meant by the choice of decree and/or action is the response or attitude of the Government Official in implementing or not implementing Government Administration in accordance with the provisions of the legislation".

Material weaknesses (substantial), namely weaknesses related to the substance or content of the article, namely:

1. According to Barda Nawawi Arief (2012), capital punishment as a criminal charge is only threatened for certain corrupt acts as in Article 2 paragraph (1) of the Corruption Eradication Act, namely: "Committing acts of enriching oneself or other people or corporations in violation of the law". When referring to the General Explanation of the Law on the Eradication of Corruption, the aim of the Law on the Eradication of Corruption is to eradicate "every form of corruption". With the formulation of the death penalty in the Corruption Eradication Act only for the types of acts as stated in Article 2, it means that capital punishment is not possible to be imposed on criminal acts other than and the rest.

2. The formulation of criminal threats in Article 2 paragraph (2) of the Law on the Eradication of Corruption is a criminal offense against offense in Article 2 paragraph (2) which is threatened with life imprisonment or a maximum prison sentence of 20 years.

Corruption is threatened with life imprisonment or a maximum imprisonment of 20 years in the Corruption Eradication Act not only criminal offenses as stated in Article 2 above. Some formulations of types of criminal acts contained in the Corruption Eradication Act which are threatened with life imprisonment or a maximum sentence of 20 years imprisonment include: Abuse of authority/opportunity/facility/because of office or position 
(Article 3); Acceptance of Bribery (passive bribery) by civil servants/state administrators, judges and advocates (Article 12). When viewed from the nature of corruption as an offense for office, the act of "abusing the authority of the office/position" (Article 3) and "accepting bribes by civil servants/state abuse, judges and advocates" (Article 12), the substance is more reprehensible than "enriching themselves" , or at least it must be viewed as equal and therefore also deserves to be threatened with capital punishment, especially the offense of bribery is the most prominent in various corruption cases so far.

1. The imposition of capital punishment in Article 2 paragraph (2) is only aimed at "people". There are no criminal charges against corporations that commit acts of corruption in "certain circumstances" as mentioned above. Although capital punishment cannot be imposed on corporations, there should also be criminal charges for corporations whose weight can be identified with capital punishment, for example by revocation of business licenses for ever or corporate dissolution/closure.

2. The formulation of the existence of "certain conditions" required in the Elucidation of Article 2 paragraph (2) of the PTPK Law is very difficult to fulfill or rarely occurs. "Certain circumstances" according to Barda Nawawi Arief are "conditional/situational reasons". These conditional/situational reasons include: the state is in danger, there is a national natural disaster, and there is a monetary economic crisis.

According to the author, "conditional/situational reasons" as stated by Barda Nawawi Arief mentioned above will indeed be difficult to realize or occur. This is based on the juridical meaning and the opinions of scholars regarding "certain circumstances" namely:

\section{- Hazard Management;}

The regulation regarding the state of danger or "State emergency" is regulated in Article 12 of the 1945 Constitution of the Republic of Indonesia which reads "The President declares a state of danger. The conditions and consequences of the hazard situation are determined by law. " At present the applicable law is Law (Prp) Number 23 of 1959 concerning Dangerous Conditions. Article 1 paragraph (1) states:

"A state of danger with a degree of civil emergency or military state or state of war, occurs when:

1. Security or law order in all regions or parts of the Republic of Indonesia are threatened by rebellion, riots or due to natural disasters, so that it is feared that they cannot be handled normally by equipment;

2. The war arises or the danger of war or the rape of the territory of the Republic of Indonesia is feared in any way;

3. The life of the State is in danger or from special conditions, it turns out there is or is feared that there are symptoms that can endanger the life of the State ".

Provisions regarding compulsory urgency are also contained in Article 22 paragraph (1) of the 1945 Constitution of the Republic of Indonesia which reads: "In the case of compulsory urgency, the President has the right to stipulate government regulations as a substitute for the law." The meaning in the provision of Article 22 paragraph (1) of the 1945 Constitution of the Republic of Indonesia NRI mentioned above, the Constitutional Court has provided an interpretation of the "compelling urgency" in the Constitutional Court's decision Number: 138/PUU-VII/2009. In the ruling, the Constitutional Court is of the opinion that there are 3 (three) conditions for forced coercion as referred to in Article 22 paragraph (1) of the 1945 NRI Constitution, namely:

1. "There are circumstances namely the urgent need to resolve legal issues quickly under the law;

2. The required law does not yet exist so that there is a legal vacuum, or there is a law but it is not adequate;

3. The legal vacuum cannot be overcome by making the law in the usual procedure because it will require quite a long time while the urgent situation needs certainty to be resolved ".

\section{- National Natural Disasters;}

The requirements for determining national disasters are regulated in RI Law Number 24 Year 2007 concerning Disaster Management (Disaster Management Law). Article 7 paragraph (2) of the Disaster Management Law states:

"Determination of the status and level of national and regional disasters as referred to in paragraph (1) letter c contains indicators which include:

a. Number of victims;

b. Property losses;

c. Damage to infrastructure and facilities;

d. Wide coverage of the area affected by the disaster; and

e. The socio-economic impact caused ". 
Regarding the meaning of "social unrest", Sulaeman Munandar (2009) gave the following definition:

"That in fact the phenomenon of social unrest that often arises lately is an indicator of the ongoing process of social transformation, in the form of representation of the clash of social values and religious values and that there is a shift in the setting of mastery of strategic resources in the form of power or politics and the economy".

As a result of this social unrest cannot be underestimated, this is because social unrest can break the foundation of the existence of the Indonesian people themselves by reason of differences in ethnicity, race, religion and class. So that acts of corruption carried out in these circumstances will muddy the social atmosphere of the Indonesian people.

\section{- Mitigation of the Economic and Monetary Crisis;}

According to economists, the understanding of the economic crisis is simply: "A condition where a country whose government cannot be trusted by its people, especially financial problems (Sari, 2016). Identification of variables that potentially cause a monetary crisis, namely:

a. "Economic growth;

b. Exchange Rates (Exchange Rates);

c. Total Money Supply;

d. Inflation;

e. Interest rate;

f. Composite Stock Price Index;

g. Balance of Payments;

h. Debt Payment Ratio (Debt Service Ratio (DSR)" (www.bi.go.id:http://www.go.id).

Barda Nawawi Arief said, related to "certain circumstances" in the form of "crime countermeasures" (recidive) which he referred to as juridical reasons, the most likely to occur. In this case the authors disagree. In terms of meaning, repetition of a crime or known as a recidive is the behavior of someone who repeats a criminal act after being convicted by a decision of a judge who has permanent legal force because the criminal act has been committed first. A person who often commits a criminal act, and because of his actions that have been sentenced to a criminal even more often sentenced to a criminal is called a residivist. If the residive shows the behavior of repeating a crime, then the residivist refers to the person who commits the repeat of the crime (Ali, 2015).

In the context of repetition of corruption, this is very difficult to do. This is because the repetition of corruption is also influenced by one of the positions held by the perpetrators, in this case the residivist of the criminal act of corruption must be in the same position as in the previous corruption.

Based on the explanation above related to the formulation of the death penalty in the Corruption Eradication Act which left many weaknesses, according to the author, the policy of the formulation of the death penalty in the Corruption Eradication Act is very difficult to implement so it is not surprising since the enactment of the Corruption Eradication Act in the year. 1999 up to now, which has been running for 20 (twenty) years, there has not been a single person who has committed a criminal act of corruption (corruptor) who has been sentenced to death. Therefore, it becomes a very urgent need to immediately amend the Corruption Eradication Act which regulates the death penalty formulation policy in the Corruption Eradication Act more explicitly, clearly and comprehensively.

In order to better anticipate the future (futuristic) so that it will not be more tragic repetition of corruption cases until there is a verdict free of corruptors from a judge who examines and decides the accused of corruption, if a verdict occurs (vrijspraak) in a criminal act of corruption will clearly bring a bad impression and precedent for the world of justice, ordinary people of the law are still difficult to accept the existence of a free verdict (vrijspraak/acguittal) if the defendant is a corruptor. There have been many studies on acquittal in corruption cases, but it has been hindered from being able to influence the facts and phenomena concerning criminal acts which are classified as very detrimental to the nation (Pasaribu, et al. 2008).

\subsection{Legal Construction of Death Criminal Threats in Corruption Perspective Ius Constituendum}

The criminal law formulation policy in the framework of tackling future criminal acts of corruption has actually been pursued, namely through the drafting of a Law (RUU) on the Eradication of Corruption (2015 PTPK Draft Bill) (http://reformasihukum.org/file/peraturan/RUTipikor). The draft bill refers to the 2003 United Nations Convention Against Corruption (UNCAC) convention, in which the consideration of the Corruption Eradication Bill was emphasized:

"Whereas with the 2003 United Nations Convention Against Corruption (UNCAC) ratification (2003 Anti-Corruption Nations Convention) with RI Law Number 7 of 2006 concerning Ratification of the 2003 United Nations Convention Against Corruption (2003 Anti-Corruption Nations Convention), then RI Law Number 31 of 1999 concerning Eradication of Corruption 
Crimes as amended by RI Law Number 20 of 2001 needs to be adjusted to the 2003 Anti-Corruption Nations Convention".

The Department of Justice's National Legal Development Agency in the National Criminal Law Reform Symposium, said that: "The renewal of criminal law is one of the major problems in the development of national law facing the Indonesian people. Renewed criminal law is a comprehensive change that includes renewal of material criminal law (substantive), formal criminal law (criminal procedural law) and criminal implementation law (strafvollstreckungsgesetz). The main purpose of criminal law reform is to tackle crime as it is well known that the three areas of law are very closely related.

According to the "vom psychologishen zwang" theory related to the principle of legality of Von Feurbach, this theory basically recommends that in determining the acts that are prohibited in the regulations not only about the types of actions that must be written clearly, but also about the kinds of crimes that are threatened. In this way, then the person who will commit the prohibited act beforehand has known what criminal will be imposed on him if later the act is committed (Moeljatno, 1978). In the 2015 Corruption Eradication Bill, the definitions or use of terms regarding certain matters in Chapter I (General Provisions) are as follows:

Article 1 of this Law is meant by:

1. "Corporation is a group of people and/or assets that are organized, whether they are legal entities or not legal entities;

2. Public Officials are:

a. Everyone who holds legislative, judicial, or executive positions that are appointed or elected permanently or temporarily is paid or not paid regardless of that person's seniority;

b. Everyone who carries out public functions including for the benefit of a public agency or public company or who provides public services based on statutory regulations;

c. Everyone who is appointed as a public official in the legislation.

3. Foreign Public Officials are:

a. Everyone who holds an executive, legislative or judicial position of a foreign country based on appointment or election, including all levels and sections of government;

b. Everyone who carries out public functions for the benefit of a foreign country, including public agencies or foreign public companies; or c. Any official or representative of an international public organization.

1) Official of a Public International Organization is any international civil servant or any person who is given authority by that organization to act on behalf of that organization;

2) Wealth is any form of assets, whether corporate or non-corporate, movable or immovable, tangible or intangible, and legal documents or instruments that prove the rights or interests of these assets;

3) Confiscation is a series of investigative actions to take over and/or keep under his control movable or immovable, tangible or intangible objects for the purposes of investigation, prosecution and trial;

4) Deprivation is a permanent takeover of assets by a court decision or other authorized body;

5) Original Criminal Acts are every criminal act that results in a criminal offense that is the object of another crime;

6) Criminal Action Results are any assets obtained directly or indirectly from a criminal act; 7. Gifts or promises are any forms that provide benefits or enjoyment for those who receive"

The definitions set out in Chapter I (general provisions) mentioned above seem to adjust to the editors at the 2003 UNCAC convention, namely:

Article 2. Use of terms:

For the purposes of this Convention:

a) "Public official" shall mean: (i) any person holding a legislative, executive, administrative or judicial office of a State Party, whether appointed or elected, whether permanent or temporary, whether paid or unpaid, irrespective of that person's seniority; (ii) any other person who performs a public function, including for a public agency or public enterprise, or provides a public service, as defined in the domestic law of the State Party and as applied in the pertinent area of law of that State Party; (iii) any other person defined as a "public official" in the domestic law of a State Party. However, for the purpose of some specific measures contained in chapter II of this Convention, "public official" may mean any person who performs a public function or provides a public service as defined in the domestic law of the State Party and as applied in the pertinent area of law of that State Party;

b) "Foreign public official" shall mean any person holding a legislative, executive, administrative or judicial office of a foreign country, whether appointed 
or elected; and any person exercising a public function for a foreign country, including for a public agency or public enterprise;

c) “Official of a public international organization” shall mean an international civil servant or any person who is authorized by such an organization to act on behalf of that organization;

d) "Property" shall mean assets of every kind, whether corporeal or incorporeal, movable or immovable, tangible or intangible, and legal documents or instruments evidencing title to or interest in such assets;

e) "Proceeds of crime" shall mean any property derived from or obtained, directly or indirectly, through the commission of an offence;

f) “Freezing" or "seizure" shall mean temporarily prohibiting the transfer,nconversion, disposition or movement of property or temporarily assuming custody or control of property on the basis of an order issued by a court or other competent authority;

g) “Confiscation", which includes forfeiture where applicable, shall mean the permanent deprivation of property by order of a court or other competent authority;

h) "Predicate offence" shall mean any offence as a result of which proceeds have been generated that may become the subject of an offence as defined in article 23 of this Convention".

Some of the articles on corruption in the 2015 Corruption Eradication Bill seem to be adjusted to the editors of the 2003 UNCAC Convention, which are regulated in several articles, including:

- $\quad$ Article 2 of the Corruption Crime Eradication Bill:

1) "Any person who promises, offers, or gives directly or indirectly to a Public Official an improper advantage for the benefit of the official himself, another person or the Corporation, so that the official does or does not do anything in the performance of his post;

2) Public Officials who request or receive directly or indirectly an improper advantage for the benefit of the official himself, another person or the Corporation, so that the Public Official does or does not do anything in the performance of his duties."

The formulation of a criminal offense in Article 2 of the above PTPK Bill is an editorial adjustment in Article 15 of the 2003 UNCAC Convention which is as follows: a) "Promises, offers, or giving to public officials, directly or indirectly, undue benefits, for public officials in their official duty capacity or other persons or bodies so that officials act or stop acting in carrying out their official duties ;

b) Requests or acceptance by a public official, directly or indirectly, undue benefit, for the public official in the capacity of his official duties or other persons or bodies so that the official acts or stops acting in carrying out official duties".

As a step in criminal law policy in tackling corruption, the Draft Bill of the 2015 Criminal Code formulates criminal acts of corruption in chapter XXXII regarding criminal acts of corruption, as stipulated in Article 680, Article 681, Article 682 (scope of bribery). Article 683, Article 684, Article 686, Article 687 (Scope of abuse of authority that harms State Finances). In other parts of the category as a criminal act of corruption, it is also regulated in the concept of the 2015 Criminal Code Bill regarding Position Criminal Acts regulated in Chapter XXX Article 655, Article 658, Article 659, Article 660, Article 662, Article 663, Article 664.

As a step in criminal law policy in tackling corruption, the Draft Bill of the 2015 Criminal Code formulates criminal acts of corruption in chapter XXXII regarding criminal acts of corruption, as stipulated in Article 680, Article 681, Article 682 (scope of bribery). Article 683, Article 684, Article 686, Article 687 (Scope of abuse of authority that harms State Finances). In other parts of the category as a criminal act of corruption, it is also regulated in the concept of the 2015 Criminal Code Bill regarding Position Criminal Acts regulated in Chapter XXX Article 655, Article 658, Article 659, Article 660, Article 662, Article 663, Article 664.

The nature of the formulation of corruption with the scope formulated in the 2015 Draft Criminal Code Draft is sufficient to provide a deterrent or countermeasure against corruption, especially for White Collar Crimes involving state officials, including law enforcement, as outlined in Article 660 Concept 2015 Criminal Code Bill.

Capital punishment in criminal law reform is still recognized, especially in the context of the Criminal Code Bill. The preservation of capital punishment in the renewal of criminal law is based on the idea of avoiding community demands/reactions that are revenge, emotional, arbitrary, uncontrolled, or extralegal execution. The provision of capital punishment is intended to provide emotional channels/demands of the community, the unavailability of capital punishment in the Act, is not a guarantee 
of the absence of capital punishment in reality in the community, therefore to avoid emotions of personal/community revenge that are not rational, it is considered more good and wiser if the death penalty is still maintained its existence in the Act (Arief, 2012).

Death penalty charges against perpetrators of corruption have been carried out throughout the course of law enforcement against perpetrators of corruption in Indonesia. This was done by the prosecutor/public prosecutor to the defendant Ahmad Sidik Mauladi Iskandardinata alias Dicky Iskandardinata in the Decision of the South Jakarta District Court No. 114/Pid.B/2006/PN. Jak Cell. that has permanent legal power with the Judicial Review decision is decision Number: 114 PK/Pid.Sus/2008. Based on the decision, it was found that the defendant was legally and convincingly guilty of committing a criminal act of corruption which was carried out jointly and continuously.

The case of the defendant above is carried out jointly and continuously is a reason that aggravates the criminal, so it is not wrong if the prosecutor/public prosecutor in his lawsuit demands the defendant with capital punishment or death sentence. Decision handed down by the judge in the South Jakarta District Court against the defendant Ahmad Sidik Mauladi Iskandardinata or Dicky Iskandardinata is a 20-year prison sentence upheld by the decision of the Jakarta High Court No. 175/Pid/2006/PT.DKI and the cassation ruling namely the Supreme Court's Decision No. $181 \mathrm{~K} / \mathrm{Pid} / 2007$ and the Judicial Review decision is decision No. 114 PK/Pid.Sus/2008, with a sentence of 20 years imprisonment means that the demands submitted by the public prosecutor/prosecutor were not granted.

Observing from what has been explained above, it is difficult for the judge to give a death sentence to a defendant in a corruption case who commits a criminal act of corruption other than with the reasons stated in the explanation of Article 2 paragraph (2) of the Corruption Eradication Act. According to the author there are a number of things that should be considered or justified in constructing the formulation of the threat of capital punishment in eradicating future criminal acts of corruption (the Corruption Eradication Bill), namely:

1) "In the formulation of articles governing acts of corruption with capital punishment in the future not only formulated with 1 (one) article provisions but can be formulated with several article provisions, such as regarding the concept of "certain conditions" contained in the explanation of Article 2 paragraph ( 2) The current Act on the Eradication of Corruption, namely the handling of dangerous situations, national natural disasters, countermeasures due to widespread social unrest, handling of economic and monetary crises, and repetition of criminal acts of corruption. The norm arrangement that regulates the limitative conditions must be the norm rather than the substance contained in the explanation so that in imposing capital punishment to the perpetrators of corruption that have fulfilled certain elements of the said condition, it can be implemented properly or imposed.

2) If a criminal act of corruption is carried out in an organized manner and continues to be organized; The point in this case is that the act was carried out by more than 1 (one) person in a way that is used very neatly to cover up an act which causes a loss of state finances or the state's economy in large enough quantities. The continuing action referred to in this matter is the act carried out continuously so as to cause financial or economic losses to the country. According to the author, if a criminal act of corruption is carried out with elements that aggravate the crime, namely that together and continuing it is appropriate to be threatened and sentenced to death.

3) If a criminal offense is committed by a state official; That the understanding of state officials as regulated in Article 1 Number 4 of the Law of the Republic of Indonesia Number 43 of 1999 concerning Amendment to the Law of the Republic of Indonesia Number 8 of 1974 concerning Personnel of Personnel, State Gazette Number 169 of 1999, Supplement to State Gazette Number 3890 is: "The leaders and members of the highest/highest state institutions as the 1945 Constitution of the Republic of Indonesia and Other Officials are determined by the Law. According to the author, if a criminal act of corruption is committed by a state official, it is appropriate to be rewarded or sentenced to death.

4) If corruption is continued with money laundering; Whereas criminal acts of corruption and money laundering constitute 2 (two) criminal acts which are currently rife, not a few people who commit criminal acts of corruption are followed by money laundering, this is done with the intent to clean up the money they get from criminal acts. According to the author it is also appropriate if someone who commits corruption and is aggravated by the crime of money laundering is sentenced to death.

5) By providing a minimum sentence of 20 years imprisonment, life imprisonment, and capital punishment. Each refers to the value of the state loss. For example, the State of China which is a capital punishment for perpetrators of criminal acts of 
corruption based on the provisions of Article 386 and Article 838 of the Chinese Penal Code which is no less detrimental to the country 100,000 Yuan or Rp. $200,000,000.00$ (two hundred million rupiah)" (https://www.kompasiana.com/rekamahrdika/55010e e1a333113e095111e5/perbandingan-uptodate-

hukum-cina-dan-indonesia-terkait-korupsi).

By taking the parameters of the value of corruption as applied in the State of China, then if it is applied in Indonesia with the state loss value model for example Rp. 10,000,000,000 (ten billion rupiah), then this will certainly make state officials think again about committing criminal acts of corruption. It also needs to be understood that in the imposition of severe criminal sanctions such as capital punishment many factors such as the ideologicalpolitical-sociological-legal aspects (Syamsudin, 2010).

\section{Conclusions}

Based on the descriptions of the chapter above, conclusions can be drawn to answer the problems contained in this scientific paper, namely:

1. The threat of capital punishment in the current laws and regulations on corruption (ius constitutum) is regulated in Article 2 paragraph (2) of the Republic of Indonesia Law No. 31 of 1999 jo. RI Law Number 20 of 2001 concerning Eradication of Corruption Crimes. Since the ratification of the Corruption Eradication Act, no corruption actor has been sentenced to death, this is due to weaknesses in the Corruption Eradication Act related to the formulation of Article 2 paragraph (2), namely the phrase "state Certain "reasons for criminal prosecution were not formulated explicitly in the formulation of the article, also the phrase" certain circumstances "in Article 2 paragraph (2) is further regulated in the Elucidation section of Article 2 paragraph (2) of the Corruption Eradication Act. Such formulation or construction of Article 2 paragraph (2) creates a vague norm. In addition, the existence of the phrase "can" in Article 2 paragraph (2) of the Law on the Eradication of Corruption, gives an understanding that the imposition of capital punishment can be applied or may not be applied.

2. The threat of capital punishment in the laws and regulations of corruption in perspective ius constituendum, is associated with the policy formulation of criminal law in the context of overcoming the criminal act of corruption that will actually have been attempted in the process of drafting the Law (RUU) on Eradicating Corruption compiled based on the 2003 United Nations Convention Against Corruption (UNCAC) Convention. The death penalty should be handed down to corruptors if the criminal act of corruption is carried out in an organized manner, if the criminal act of corruption is carried out by state officials, if the criminal act of corruption is followed by money laundering.

\section{References}

1. Ali, M. (2015). Dasar-Dasar Hukum Pidana, Jakarta, PT. Sinar Grafika.

2. Amri, A. (2007). Ilmu Kedokteran Forensik. Medan, Bagian Ilmu Kedokteran Forensik, USU Press.

3. Amidhan. (2006). Catatan Akhir Tahun 2006 Tentang Perlindungan dan Pemenuhan Hak Ekonomi, Sosial, dan Budaya. Jakarta, Komnas HAM.

4. Arba'i, Y.A. (2012). Aku Menolak Hukuman MatiTelaah Atas Penerapan Pidana Mati, Jakarta, Kepustakaan Populer Gramedia.

5. Arbi, S.Z. \& Ardana, W. (1997). Rancangan Penelitian dan Kebijakan Sosial, Jakarta, CV. Rajawali.

6. Arief, B.N. (2012). Pidana Mati, Perspektif Global, Pembaharuan Hukum Pidana dan Alternatif Pidana untuk Koruptor. Semarang, Pustaka Magister.

7. Atmasasmita, R. (2005). Pengantar Hukum Kejahatan Bisinis, Jakarta, Kencana.

8. Azhar. (2009). Peranan Biro Anti Korupsi dalam Mencegah Terjadinya Korupsi di Brunei Darusalam, Article in Journal Litigation, Faculty of Law Unpas, Bandung, Vol.10

9. Buckley, M. \& Hans Otto Sano. (2003). Hak Asasi Manusia dan Good Governance, Membangun Suatu Ketertiban, Jakarta, Depkumham.

10. Diantha, I M.P. (2017). Metodelogi Penelitian Hukum Normatif Dalam Yuridiksi Teori Hukum, Jakarta, Prenada Media Group.

11. Hamzah, A. (1995). Delik-Dellik Tersebar di Luar KUHP dengan Komentar, Jakarta, Pradnya Paramita.

12. Harkrisnowo, H. (2002). Korupsi, Konspirasi, dan Keadilan di Indonesia, Journal of Dictum, LeIP, Edition I, Jakarta, Lentera Hati.

13. Indriyanto Seno Adji, 2006, Korupsi Kebijakan Aparatur Negara dan Hukum Pidana, Diadit Media, Jakarta.

14. Kholik M., A. (2011). Eksistensi KPK dalam Peradilan Korupsi di Indonesia, Article in Journal Law Faculty of Law UII, Vol.11, No.26.

15. Koeswadji, H.H. (1994). Korupsi di Indonesia dari Delik Jabatan ke Tindakan Pidana Korupsi, PT. Bandung, Citra Aditya Bakti. 
16. Lamintang, P.A.F. (2010). Hukum Penitensier di Indonesia, Bandung, Armico.

17. Lubis, T.M. \& Lay, A. (2009)., Kontroversi Hukuman Mati: Perbedaan Pendapat Hakim Konstitusi, Jakarta, Kompas Media Group.

18. Moeljatno. (1978). Asas-Asas Hukum Pidana, Yogyakarta, UGM.

19. Muhammad, Y. (2013). Merampas Aset Koruptor: Solusi Pemberantasan Korupsi di Indonesia, Jakarta, Buku Kompas.

20. Mulyadi, L. (2012). Hukum Acara Pidana Indonesia, Bandung, Alumni.

21. National Criminal Law Reform Symposium Organized by the National Law Development Board, Ministry of Justice in Collaboration with Diponegoro University, Semarang, August 28-30, 1980 in the National Criminal Law Reform Symposium, Bina Cipta, Bandung

22. Nitibaskara, R.R. (2005). Tegakkan Hukum Gunakan Hukum, Jakarta, Kompas.

23. Obokata, T. (2015). The Value of International Law in Combating Transnational Organized Crime in the AsiaPacific, Asian Journal of International Law, Vol.07

24. Pasaribu, L.H., Jauhari, I \& Zahara, E. (2008). Kajian Yuridis Terhadap Putusan Bebas Tindak Pidana Korupsi (Case Study at the District Court of Medan), Journal of Marcatoria, Vol.01.

25. Passas, N. (2003). Cross-Border Crime and the Interface Between Legal and Illegal Actors, Security Journal Vol. 16, No.01

26. Prodjohamidjojo,M. (2009). Penerapan Pembuktian dalam Delik Korupsi, Bandung, Mandar Maju.

27. Ridwan. (2009). Peningkatan Kesejahteraan Rakyat Melalui Pendekatan Ekonomi Kerakyatan di Kabupaten Serang, Article in Magazine Dinamika, Vol.34, No.04.

28. Saleh, R. (1978). Masalah Pidana Mati, Jakarta, Akasara Baru.

29. Sari, P.K. (2016). Identifikasi Penyebab Krisis Moneter dan Kebijakan Bank Sentral di Indonesia: Kasus Krisis Tahun 1977-1998 dan 2008, Scientific Journal of Student Economics Development and Business Economics Unsyah, Vol.01, No.02.

30. Soelaeman, M. (2009). Sosiologi: Suatu Pengantar, Jakarta, PT. Raja Grafindo Persada.

31. Sudarto. (2007). Hukum dan Hukum Pidana, Bandung, Alumni.

32. Supandi, H. (2008). Eksistensi Pidana Mati dalam Proses Penegakan Hukum di Indonesia, Journal of European Area Studies, Vol.04, No.02
33. Syamsudin, M. (2010). Faktor-Faktor Sosiolegal yang Menentukan dalam Penanganan Perkara Korupsi di Pengadilan, Journal of Law, Vol.17., No.03

34. Waluyadi. (2009). Kejahatan Pengadilan dan Hukum Pidana, Bandung, Mandar Maju.

35. Winandi, W. \& Lukito, I.R.(2010). Penjatuhan Pidana Mati dalam Tindak Pidana Narkotika, Journal of Law, Vol. XIX, No.19 October 2010

\section{Internet References}

36. Krisis Ekonomi Global dan Dampak Terhadap Perekonomian Indonesia, accessed via: https://www.bi.go.id, on May 25, 2020 at 6:40 pm 37. Nasional Kompas.com, Indeks Persepsi Korupi Indonesia Naik Jadi 40, diakses dari: https://nasional.kompas,com/read/2020/01/23/16565951/in deks-persepsi-korupsi-indonesia-pada-2019 naik-jadi-40, on April 28, 2020 at 7:30 a.m.

38. Perbandingan Uptodate Hukum dan Indonesia terkait Korupsi, accessed via : https://www.kompasiana.com/rekamahardika/550ioee1a33 3113e095111e5/Perbandingan-Uptodate-hukum-danindonesia-terkait-korupsi, on May 25, 2020 at 19.34 pm

\section{Laws And Regulations Academic References}

39. Text and Draft Act (RUU) on the Eradication of Corruption in 2015

40. General Assembly Resolution 58/4 of 31 October 2003 UNCAC, Article 2, Article 15

41. Decision of the South Jakarta District Court Number: 114/Pid.B/2006/PN.Jak.Sel jo. MA-RI PK Decision Number: 114 PK/Pidsus/2008

42. Law of the Republic of Indonesia Number 31 of 1999 concerning Eradication of Corruption; Republic of Indonesia State Gazette Year 1999 Number 140; Supplement to the State Gazette of the Republic of Indonesia Number 387

43. Law of the Republic of Indonesia Number 30 of 2002 concerning the Corruption Eradication Commission; Republic of Indonesia State Gazette Year 2002 Number 137; Supplement to the State Gazette of the Republic of Indonesia Number 4250

44. Law of the Republic of Indonesia No. 7 of 2006 concerning Ratification of the United Nations Convention Against Corruption, 2003; Republic of Indonesia State Gazette Year 2006 Number 32; Supplement to the State Gazette of the Republic of Indonesia Number 4620

45. Law of the Republic of Indonesia Number 46 of 2009 concerning Corruption Criminal Court; Republic of Indonesia State Gazette Year 2009 Number 155; 
Supplement to the State Gazette of the Republic of Indonesia Number 5074. 